\title{
The identity of architectural and lighting solutions of stone mosques of the late XVIII - early XX centuries in Kazan
}

\author{
Olga Rachkova ${ }^{1}$, and Albina Khabibulina ${ }^{1 *[0000-0003-2928-2884]}$ \\ ${ }^{1}$ Kazan State University of Architecture and Engineering,420043, Zelenaya st. 1, Kazan, Russia
}

\begin{abstract}
The work aims to analyze the influence of translucent fences on the light environment in the prayer hall and internal premises with the traditional volumetric-spatial solution of stone mosques of the late XVIII early XX centuries in Kazan (Republic of Tatarstan, Russia). Based on the study of stone mosques in Kazan it was revealed that the main factor was the creation of a complete architectural image of the mosque following the temporary style and solution of the internal light environment through windows and stained-glass windows. Windows and stained-glass windows were scaled using architectural elements and decor for the holistic perception of the object. The significance of the obtained results for architecture is to present recommendations for the organic use of the studied techniques and methods of work on the objects of the architectural heritage in the restoration and design of modern mosques.
\end{abstract}

Keywords: stone mosques, volumetric-spatial and light environment, Islamic architecture, national traditions.

\section{Introduction}

Daylight is fundamental for visual comfort and for ensuring optimal sanitary and hygienic parameters of the premises. Much attention paid to the theory of natural light meaning, its functional and aesthetic aspects in the architectural space [1-3].

The assessment of daylight illumination in medieval stone structures in Europe is considered in the works of foreign scientists. The assessment is based on both the measurement of daylight and its modelling $[4,5]$. Natural light and the artificial lighting treatmenthave a particular impact on the atmosphere of sacred spaces. Light and shadow have a special meaning for sacred space. Light can accentuate and direct attention, create an atmosphere of contemplation and tranquillity, promote unity in prayer, emphasizing the solemnity or festivity of an event [6-9].

Considering the development of Islamic architecture and urbanism in the late medieval city, authors note its orientation towards local traditions and the search for its own identity [10-13]. The mosque is a traditional symbol of Muslim architecture. Studying the historical experience of the construction of mosques, authors considered the particular attention of

\footnotetext{
${ }^{*}$ Corresponding author: albgomer@mail.ru
} 
architects to signs and metaphors in the formative elements, compositional and planning principles.

In this case, natural light has a certain quality value in identifying the space of religious Muslim architecture [14-16].

Foreign [17-20] and Russian [21, 22] architects, restorers, and art critics currently reflected in their works the problems of natural lighting of Muslim religious buildings. The studies of foreign scientists presented systems of organizing natural lighting in Tunisian and Algerian mosques of the Ottoman era, Iran, Turkey. Scientists' research is aimed at studying and preserving monuments of architectural heritage and using the experience of ancient architects in the design of modern mosques. Based on typological, topological and morphological analysis of architectural objects, authors discussed the use of daylight in religious buildings and its significance.

The creation of a volumetric-spatial solution of a religious building and its light environment due to natural lighting, provides significant energy saving and environmental friendliness, bringing it closer to the «green standards». The design in the solution of the walls, floor, and ceiling creates an atmosphere of inner tranquillity and the mood for performing religious rituals. The use of artificial lighting in mosques, which have the status of architectural heritage sites or in modern buildings can create uneven and uncomfortable lighting for worshipers.

The key aspect of the Kazan stone mosques of the studied period is a clear tracing of national characteristics related to the ancient traditions of the wooden mosques' construction [22-24].

The main task of the work is to study the volumetric-spatial solutions and the light environment of local stone mosques, due to translucent fences, their mutual influence on each other, as well as the influence of the canons and rules of Islam on the design of religious buildings. The physical and measurable aspects of natural light are outside the scope of this article.

\section{Materials and methods}

Kazan stone mosques of the late XVIII - early XX centuries are the monuments of architecture of the Federal and Republican categories and included in the «List of cultural heritage sites» (CHS).

Authors selected for the analysis the most significant stone mosques of the late XVIII early XX centuries located in the central part of Kazan (Table 1).

The hierarchy of mosques included in the list for research is mainly the quarter mosques of the Mahalla and Friday Jami mosques, and the one is Nurulla Mosque (The Seventh Cathedral Mosque) on Moskovskaya street, 74/15.

The mosques on the master plan are oriented from north to south, with a strict orientation towards Mecca. Mosques are centres of religious and cultural communication. The angular arrangement of mosques in a quarter with a radius of 600 to $1200 \mathrm{~m}$ was characteristic. Cathedral mosques were located in the most significant squares of the city.

The mosques under consideration are rectangular buildings in the plan, one or two stories, with two or four pitched roofs. Depending on the size of the plan, the mosque has one or two halls. One could be a mezzanine. On the south side, the main volume is adjoined by a mihrab of a rectangular or semicircular shape, one or two stories high. Most of the mosques under consideration have two floors, where the first floor is occupied by service and utility rooms (utility rooms, storerooms, a library, etc.). There is mainly an entrance area on the north side - a vestibule, a cloakroom, an administration. Further, there was a prayer hall with a mihrab and a minbar in the southern end. According to the planning characteristics, the mosques under consideration belong to the one- or two-fold closed type. 
Table 1. Stone mosques in Kazan of the late XVIII - early XX centuries.

\begin{tabular}{|c|c|c|c|}
\hline Name of CHS & $\begin{array}{l}\text { Date } \\
\text { of construction, } \\
\text { architect }\end{array}$ & $\begin{array}{c}\text { CHS } \\
\text { category }\end{array}$ & $\begin{array}{l}\text { Registration of CHS } \\
\text { in the Unified State Register } \\
\text { (Historical and Cultural } \\
\text { Monuments) of the peoples of } \\
\text { the Russian Federation }\end{array}$ \\
\hline $\begin{array}{l}\text { The Mardjani } \\
\text { Mosque }\end{array}$ & 1766 & Federal & $\begin{array}{l}\text { № } 161711110740006 \text { Order of } \\
\text { the Ministry of Culture of the } \\
\text { Russian Federationof } 02.10 .2017 \\
\text { № } 108842-p\end{array}$ \\
\hline Apanaev Mosque & 1768 & Federal & $\begin{array}{l}\text { № } 161711110730006 \text { Order of } \\
\text { MC RF of 02.10.2017 } \\
\text { № 108906-p }\end{array}$ \\
\hline $\begin{array}{l}\text { Novo-Slobodskaya } \\
\text { Mosque }\end{array}$ & 1801-1805 & Regional & $\begin{array}{l}\text { № } 161710792280005 \text { Order of } \\
\text { MC RF of 13.04.2017 } \\
\text { № 84414-p }\end{array}$ \\
\hline Blue Mosque & $\begin{array}{l}\quad 1830, \\
\text { architect } \\
\text { A. K. Schmidt }\end{array}$ & Regional & $\begin{array}{l}\text { № } 161711110390005 \text { Order of } \\
\text { MC RF of 02.10.2017 } \\
\text { № 109049-p }\end{array}$ \\
\hline $\begin{array}{l}\text { Mosque «Iske-Tash» } \\
\text { Minaret }\end{array}$ & $\begin{array}{l}\text { 1830-1840, architect } \\
\text { A. K. Schmidt }\end{array}$ & Federal & - \\
\hline $\begin{array}{l}\text { Nurulla Mosque } \\
\text { (The Seventh } \\
\text { Cathedral Mosque) }\end{array}$ & $\begin{array}{l}1849, \\
\text { architect } \\
\text { A.I. Peske }\end{array}$ & Federal & $\begin{array}{l}\text { № } 161711110480006 \text { Order of } \\
\text { MC RF of 02.10.2017 } \\
\text { № 108393-p }\end{array}$ \\
\hline Soltan Mosque & 1867 & Regional & $\begin{array}{l}\text { № } 161711110420005 \text { Order of } \\
\text { MC RF of } 03.10 .2017 \\
\text { № 10464-p }\end{array}$ \\
\hline $\begin{array}{l}\text { Bornay Mosque } \\
\text { Minaret }\end{array}$ & $\begin{array}{l}1872 \\
\text { architect } \\
\text { P.I. Romanov }\end{array}$ & $\begin{array}{c}- \\
\text { Federal }\end{array}$ & $\begin{array}{l}- \\
\text { № } 161410159950006 \text { Order of } \\
\text { MC RF of 09.06.2015 № 579-p }\end{array}$ \\
\hline Galeev Mosque & XIX c. & Regional & $\begin{array}{l}\text { № } 161711110410005 \text { Order of } \\
\text { MC RF of } 02.10 .2017 \\
\text { № } 108549-p\end{array}$ \\
\hline Azimov Mosque & early XIX c. & Federal & $\begin{array}{l}\text { № } 161410163380006 \text { Order of } \\
\text { MC RF of } 09.06 .2015 \text { № } 582-p\end{array}$ \\
\hline $\begin{array}{l}\text { Mosque at the Tatar } \\
\text { cemetery }\end{array}$ & early XX c. & Regional & $\begin{array}{l}\text { № } 161711250870005 \text { Order of } \\
\text { MC RF of 05.12.2017 } \\
\text { № 129956-p }\end{array}$ \\
\hline $\begin{array}{l}\text { The Thousandth } \\
\text { Anniversary of Islam } \\
\text { Mosque (The } \\
\text { Mosque Across the } \\
\text { Kaban) } \\
\text { Minaret }\end{array}$ & $\begin{array}{l}\text { 1924-1926 } \\
\text { architect } \\
\text { A. Pechnikov }\end{array}$ & Federal & - \\
\hline
\end{tabular}


The minaret is the main compositional element of the volumetric-spatial composition. The call to prayer is proclaimed from the upper platform of it. The main vertical accent of the mosque is located in the center of the roof or at the northern end of the building. Less often it takes an angular position (The Thousandth Anniversary of Islam Mosque (The Mosque across the Kaban)).

The main space of the prayer hall, its size, height, decoration of the walls and ceiling surfaces, and most importantly the light environment, had to play a huge role and had a special influence on the worshipers. The use of natural light in mosques, during Salah, especially in the daytime, is perceived as one of the factors in the planning decisions of the building, while simultaneously solving issues in terms of aesthetic possibilities, through the use of not only simple window openings, but also colored stained-glass glazing.

\section{Results}

Based on the studied sources and field studies, the volumetric-spatial, structural and architectural features of mosque buildings were identified (Table 2).

Table 2. Statistical analysis of parameters, structural and architectural features of mosques.

\begin{tabular}{|c|c|c|c|c|c|c|c|c|c|c|}
\hline \multirow{2}{*}{$\begin{array}{c}\text { Name } \\
\text { Of the mosque }\end{array}$} & \multirow{2}{*}{$\begin{array}{c}\text { Architectural } \\
\text { style }\end{array}$} & \multirow{2}{*}{$\begin{array}{l}\text { Layout } \\
\text { of the } \\
\text { minaret in } \\
\text { the plan }\end{array}$} & \multicolumn{2}{|c|}{ Floors } & \multicolumn{3}{|c|}{ Windows } & \multicolumn{3}{|c|}{ Roof } \\
\hline & & & 1 & 2 & 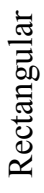 & $\begin{array}{l}\text { D্d } \\
\frac{0}{0} \\
\dot{Z}\end{array}$ & 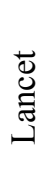 & $\begin{array}{l}\frac{0}{0} \\
\frac{\pi}{0} \\
\frac{0}{0} \\
\frac{1}{d}\end{array}$ & 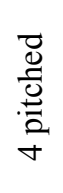 & $\begin{array}{l}\text { ̊̊ } \\
\text { ڤ̊ }\end{array}$ \\
\hline $\begin{array}{l}\text { The Mardjani } \\
\text { Mosque }\end{array}$ & $\begin{array}{l}\text { With Baroque } \\
\text { Elements }\end{array}$ & & & + & & + & & & + & \\
\hline $\begin{array}{l}\text { Apanaev } \\
\text { Mosque }\end{array}$ & $\begin{array}{l}\text { With Baroque } \\
\text { elements, Old } \\
\text { Russian patterned } \\
\text { architecture and } \\
\text { local national } \\
\text { traditions }\end{array}$ & & & + & + & + & & & + & \\
\hline $\begin{array}{l}\text { Novo- } \\
\text { Slobodskaya } \\
\text { Mosque }\end{array}$ & $\begin{array}{l}\text { With classicism } \\
\text { elements }\end{array}$ & & & + & + & & & & + & \\
\hline Blue Mosque & $\begin{array}{l}\text { With classicism } \\
\text { elements }\end{array}$ & & & + & + & & & + & & \\
\hline
\end{tabular}




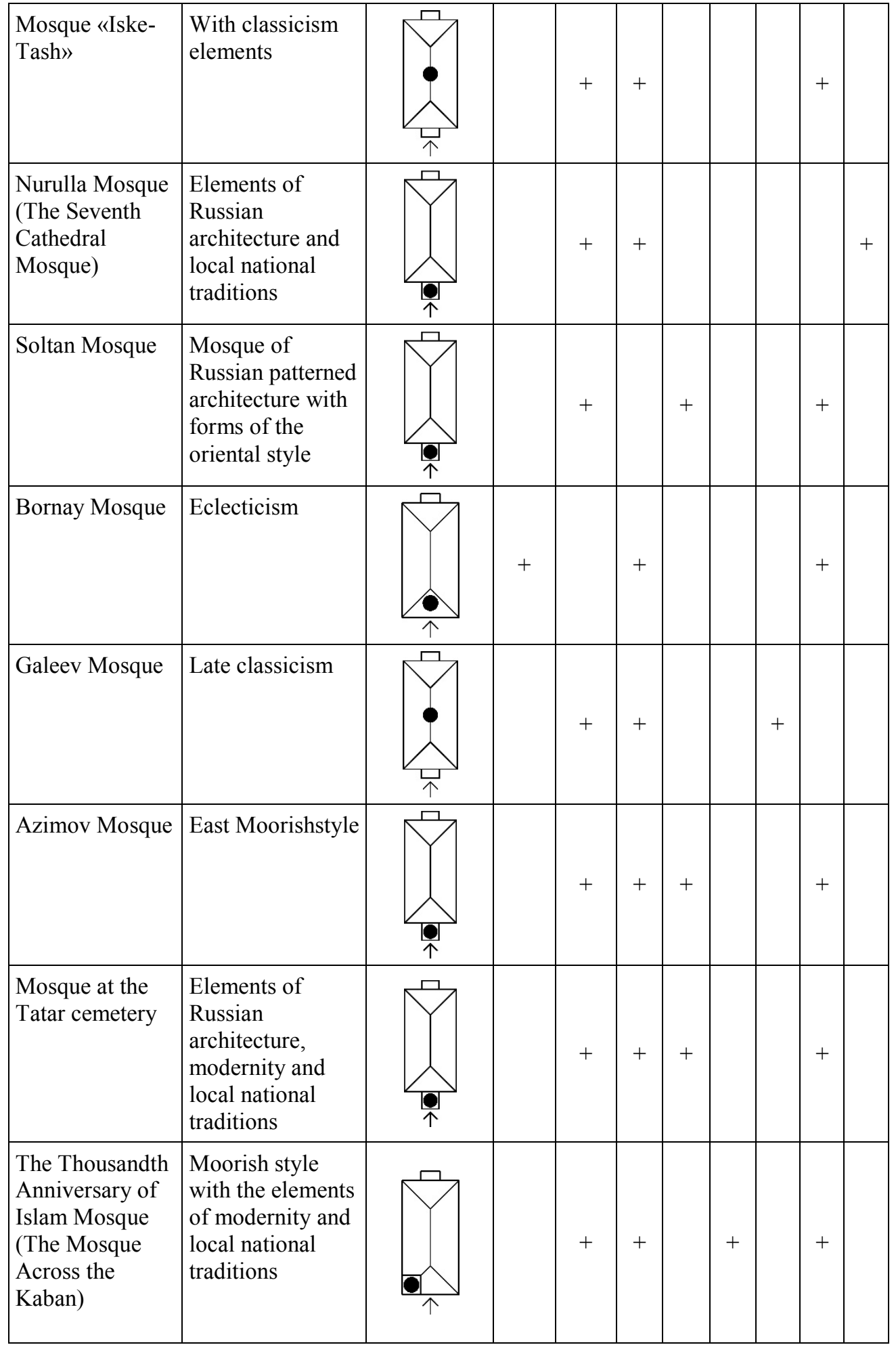


Authorscarried out a statistical analysis of the geometric dimensions of mosques in order to find the relationship between space-planning parameters (height, width, and length), structural and architectural features of the buildings under study.

Based on the studies, the following aspects have been identified that affect the natural lighting of the prayer hall and other internal premises, creating a favorable light environment in the space of the mosque:

- The shape of the openings (rectangular, arched, lancet);

- Dimensions, depending on the architectural style;

- Types of glass-transparent fencing (windows, stained-glass windows);

- Location on the facades (side, end, top);

- Location along the height of the building (single-tier, two-tier).

Typical in shape and size, window openings of the considered mosques with different architectural styles, were as follows:

- For baroque - arched windows withsandricks in the proportions of 1:2-1:2.5;

- For classicism and eclecticism - square, rectangular - in proportions of 1:1, 1:2, 1:2.5;

- For East Moorish - lancet in proportions of 1:2.5, 1:3.

The ratio between the width and length of the considered mosques was $1: 2.3-1: 3$. The height of two-story mosques along the facade to the roof is within $10 \mathrm{~m}$, the roof height is from 3 to $5 \mathrm{~m}$. The small width of the mosque, within 11-13 m, contributed to good natural, mainly side lighting, with an east and west orientation of side facades. The arrangement of the windows in one or two tiers and contributed to the ingress of natural light from sunrise to sunset (Figure).

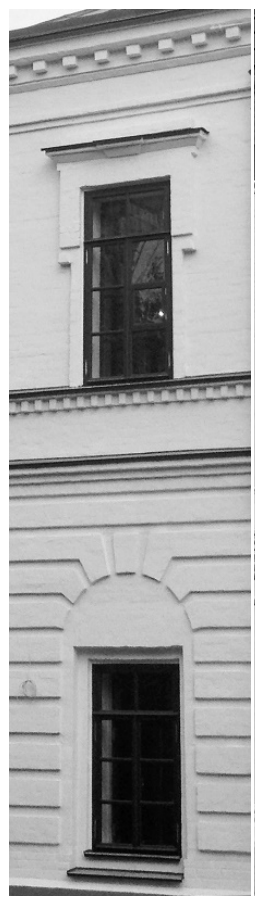

a)

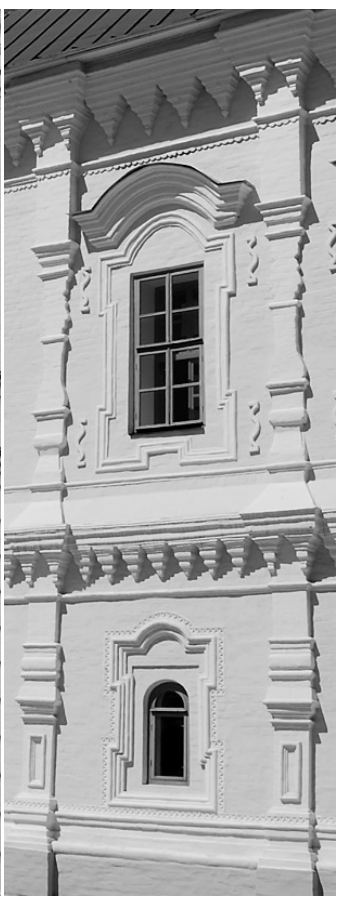

b)

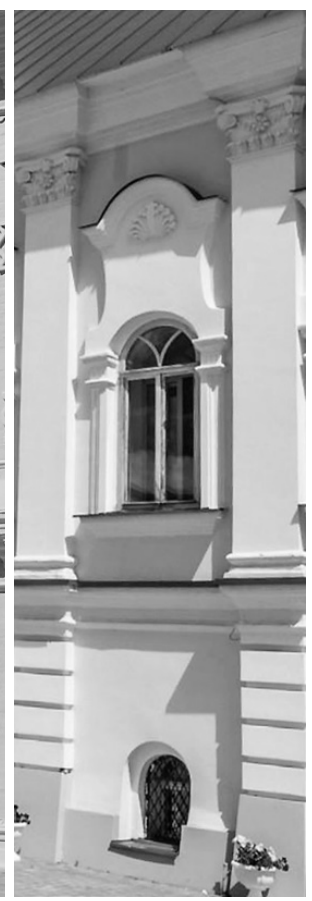

c)

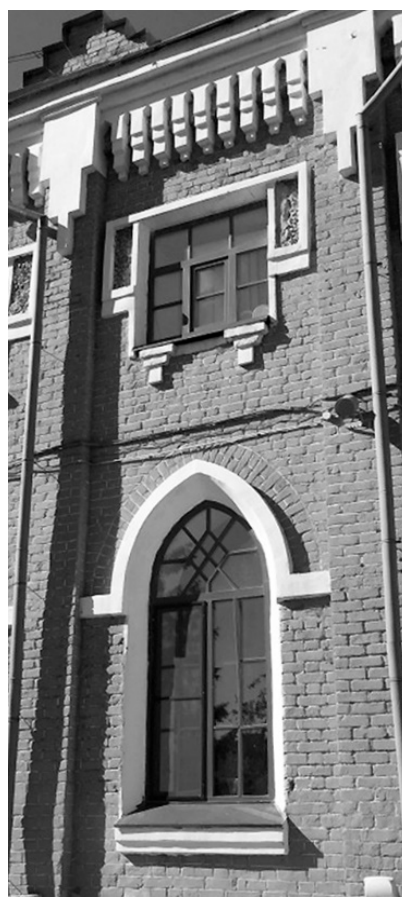

d)

Fig. Fragments of the facades of mosques. Window openings: a) Galeev Mosque - rectangular windows; b) ApanaevMosque - arched and rectangular windows; c) Mardjani Mosque- arched windows; d) The Thousandth Anniversary of Islam Mosque (The Mosque Across the Kaban)- lancet and rectangular windows (illustration by the authors). 


\section{Discussion}

Mosques in Kazan carry a certain style of architecture and a volumetric-spatial solution, which is typical for this particular territory and repelled by folk, traditional wooden architecture. At the same time, it is necessary to consider both religious traditions and canons, which can change over time, as well as design features and materials for the construction of buildings.

The volumetric-spatial composition of the mosques under consideration echoes rural wooden mosques, accentuating the local canonicity, which is characteristic of Kazan Province and differs from other regions of the Volga region, central regions of the Urals, Siberia and Crimea.

Professor Niyaz Khalit gives external proportional ratios of the mosques sizes, which characterize the holistic perception of the buildings silhouette, including Mahalla and Jami, and have a wide range of values. The environment probably influenced it. It was necessary to fit harmoniously this or that mosque into it. Since a huge positive effect is caused by the proportionality scale and visual correspondence of the building with the adjacent buildings [22, p. 115]. Niyaz Khalit emphasizes that «Islam does not reject the influence of any culture and does not prohibit borrowing the forms of religious buildings of other religions: Christian, Jewish, Buddhist, etc. - up to using the symbols of these religions in the external decoration of the building» [22, p. 9-10]. Therefore, in The Mardjani and Apanaev Mosques we find architectural elements of the Baroque style, which are typical for the period of construction of these buildings, and in the mosques of Novo-Slobodskaya, Blue, Galeev and Iske-Tash - the style of classicism.

In the architectural style of mosques, the mutual penetration of Russian and Tatar cultures, as well as the late Baroque, in particular, the Russian Baroque, which were fashionable at that time in Europe, is clearly traced. The more advanced experience of Russian architects who designed and built various types of buildings in Kazanwas taken into account.The order for the design of the mosque was considered successful when choosing a more famous architect of the city.

Architects in the past were guided not only by the local traditions of design and construction of buildings for various purposes but also by global trends in the direction of architectural styles. This was revealed when analyzing the style of mosques.

Not only the harmonious volumetric-spatial solution of the mosque due to the proportional regularity of the silhouette was important, but also the creation of an internal comfortable space for the implementation of ritual prayers and readings.

Natural lighting played an important role in the absence of electricity, and in the case of its use, it served as a factor of energy saving, which greatly contributed to the environmental friendliness of religious buildings. It was necessary to take into account not only the direct light penetration through the translucent barriers but also the reflected light from the interior surfaces since plastered, smooth walls, painted in bright colours, ceramic coatings contribute significantly to good light reflection.

Prayer halls are also used for studying students and reading the Quran during the day. The internal environment of the prayer hall also required additional lighting through window openings in the end southern wall, from the side of the mihrab and oriented towards Mecca and carrying sacred light $[25,26]$.

The height of the window openings and their dimensions could not always correspond to the internal volume and the high height of the prayer hall, and this was reflected in the external facades. For example, with the high height of the second floor, the windows on the facade look disproportionately low, as on the facade of the Mardjani Mosque. So, they were enlarged due to baroque sandricks with an arched shelf and stucco decoration under it. This visually doubled the window openings. At the Iske-Tash Mosque, the increase in 
rectangular windows was achieved by deepening the windows into niches of greater height, which formed pilaster strip (lesene) going up to the intermediate cornice. In the Bornay Mosque, the windows are bordered with frames from the simplest profile. The same effect is obtained by placing on the plane of the facade a protrusive pilaster strip pulling the facade up.

The light environment in mosques, created by natural light, could sometimes be excessive. It was regulated in various ways, through the use of stained-glass windows, carved shutters and bars.

With a single-tier arrangement of windows in the prayer hall, the level at a height of 0.8-1.0 $\mathrm{m}$ from the floor is sufficiently well illuminated, creating a favorable environment for worshipers.

In the case of two-tiered windows, the upper row of windows works more for the internal light environment at the level of half the height of the hall and for reflection from the vertical surfaces of the walls. It should be considered that natural light penetrates through the windows year-round, and solar radiation, with an intense luminous flux, only from April to September, which is typical for the territory of the Republic of Tatarstan. The most excess solar radiation can be observed in the summer months from the western side in the afternoon.

Natural illumination of premises consists of three components: illumination from direct sunlight reflected from adjacent buildings and reflected light from the interior surfaces of premises. The reflected illumination from the interior surfaces of the building is directly dependent on the interior surface finish. In this case, the reflection coefficient is of great importance. Light-colored surfaces and smooth surfaces have a light reflectance coefficient from 0.84 to 0.69 (from white to pink), and darker colored surfaces from 0.53 to 0.2 (blue, gray, green, olive green) (table 3 ).

Table 3. Reflection coefficients from surfaces of different colors.

\begin{tabular}{|c|c|c|c|c|c|c|c|c|c|}
\hline Surface color & White & Pink & Gray & Green & $\begin{array}{c}\text { Dark } \\
\text { blue }\end{array}$ & Brown & $\begin{array}{c}\text { Olive } \\
\text { green }\end{array}$ & $\begin{array}{c}\text { Dark } \\
\text { brown }\end{array}$ & $\begin{array}{c}\text { Dark } \\
\text { green }\end{array}$ \\
\hline $\begin{array}{c}\text { Reflection } \\
\text { coefficient }\end{array}$ & 0.84 & 0.69 & 0.53 & 0.41 & 0.4 & 0.23 & 0.2 & 0.15 & 0.1 \\
\hline
\end{tabular}

Also, the transmission of light through materials intended for filling windows and stainedglass windows is of great interest for the light environment design.

Ordinary or stained glass has appropriate indicators for light reflection, light transmission and light energy absorption. For example, a simple glass of $4 \mathrm{~mm}$ thick, which is frequently used in the filling of window openings, has the following distribution in terms of these indicators in $\%$ : light reflection $-8 \%$, light transmission $-88 \%$, light absorption $4 \%$.

These properties of materials for filling window frames and stained-glass windows must be taken into account, both during the restoration of architectural monuments and for the new construction of religious buildings. 


\section{Conclusion}

The studies of the light environment of Kazan stone mosques of the late XVIII - early XX centuries made it possible to identify complex architectural solutions for the formation of comfortable conditions in the prayer hall and other premises of the mosque for Salah, teaching and reading the Quran and other activities related to various services. The analytical part of the work creates the prerequisites for the development of the additional recommendations when choosing translucent structures (windows, stained-glass windows) for the restoration of mosques and the design of modern religious objects. Further work of the authors will be aimed at solving the following tasks:

1. Systematization of windows and stained-glass windows, their sizes and shapes following national traditions.

2. Calculation of the area of the translucent barrier according to the planning area of the prayer hall and other premises.

3. The choice of materials for filling windows and stained-glass windows, taking into account the transmission, absorption and reflection of solar energy.

4. Placement of windows along with the height of the facades.

5. Color scheme of stained-glass windows.

6. Color design of internal surfaces of walls, floors, ceilings, following the physical and technical indicators of reflection and light energy absorption.

\section{References}

1. I. F. Ozorhon, T. U. Uraz, Journal of Architecture and Urbanism, 38(2), 107-119 (2014) DOI: $10.3846 / 20297955.2014 .916513$

2. T. Schielke, T. Schielke, The Journal of the Illuminating Engineering Society, 15(2-3), 227-248 (2019) DOI: 10.1080/15502724.2018.1518715

3. K. Tarabieh, K. Nassar, M. Abdelrahman, I. Mashaly, Frontiers of Architectural Research, 8(3), 311 -318 (2019) DOI: 10.1016/j.foar.2019.05.004

4. J. Mohelníková, D. Mícek, S. Floreková, A. Selucká, M. Dvo`rák, Buildings, 8(5), 68 (2018) DOI: 10.3390/buildings8050068

5. R. Franchino, C. Frettoloso, F. Muzzillo, Advances in Utopian Studies and Sacred Architecture, Springer, Cham., 169-176 (2021) DOI: 10.1007/978-3-030-50765-7_14

6. R. Stegers, Birkhäuser, Springer, Cham., 247 (2008) DOI: 10.1007/978-3-7643-8276-6

7. N. S. Ramzy, International Journal of Architecture, Engineering and Construction 2(4), 219-233 (2013) DOI: 10.7492/IJAEC.2013.020

8. U. Ali Salih Al-Juboori, Al-Rafidain, Engineering Journal, 22(4), 164-183 (2014) DOI: 10.33899/rengj.2014.101533

9. S. Wing, Routledge, 320 (2015) DOI: 10.4324/9781315798226

10. H. Mortada, Routledge, 208 (2003) DOI: 10.4324/9780203422687

11. E. S. Wolper, History Compass 12(12), 912-923 (2014) DOI: 10.1111/hic3.12204

12. F. Nasrollahi, Journal of Islamic Studies and Culture, 3(2), 86-99 (2015) DOI: $10.15640 /$ jisc.v3n2a10

13. J. Mahdi Nejad, E. Zarghami, A. Sadeghi Habib Abad, Journal of Fundamental and Applied Sciences, 8(3), 1077-1096 (2016) DOI: 10.4314/jfas.v8i3.23

14. J. Nejdet Erzen, The Journal of Aesthetics and Art Criticism, 69(1), 125-131 (2011) DOI: $10.1111 / \mathrm{j} .1540-6245.2010 .01453 . x$

15. R. Arjmand, M. Mirsafa, Z. Talebi, International Handbooks of Religion and Education 7, Springer, Cham., 1-43 (2018) DOI: 10.1007/978-3-319-53620-0_54-2

16. R. Salah El Din, O. Hashim, A. Hussein, Journal of Design Sciences and Applied Arts, 1(1), 134-143 (2020) DOI: 10.21608/jdsaa.2020.70459 
17. Y. Arab, A. S. Hassan, American Journal of Environmental Sciences, 9(1), 25-32 (2013) DOI: 10.3844/ajessp.2013.25.32

18. N. I. Nordin, A. Misni, Environment-Behaviour Proceedings Journal, 2(5), 23-29 (2017) DOI: $10.21834 /$ e-bpj.v2i5.677

19. İ. A. Taştemir, Ü. Arpacioğlu, A. Coşkuner Pamuk, ICONARP International Journal of Architecture and Planning, 8, 102-123 (2020) DOI: 10.15320/iconarp.2020.145

20. M. Shahani, Space and Culture, 24(1), 19-36 (2021) DOI: 10.1177/1206331218782406

21. E. R. Kotlyar, K. S. Seitmambetova, Tavricheskiynauchnyyobozrevatel2(19), 64-67 (2017)

22. N. Kh. Khalitov, Tatarskoeknizhnoeizdatelstvo, 242 (2012)

23. Kh. G. Nadyrova, T. V. Vavilonskaya, Izvestiya KGASU, 4(50), 48-71 (2019)

24. K. G. Nadyrova, D. A. Nadyrova, IOP Conference Series: Materials Science and Engineering, 890, 012023 (2020) DOI: 10.1088/1757-899X/890/1/012023

25. I. I. El-Darwish, R. A. El-Gendy, Alexandria Engineering Journal, 55(4), 3185-3193 (2016) DOI: 10.1016/j.aej.2016.08.006

26. A. Bayraktar, E. Hökelekli, T. Türker, İ. Çalik, A. Mosallam, International Journal of Architectural Heritage, 13(4), 585-589 (2019) DOI: 10.1080/15583058.2018.1447617 